\title{
KONSEP MATERIALITAS DALAM PERSPEKTIF AUDITOR INSPEKTORAT DAERAH (STUDI PADA INSPEKTORAT KABUPATEN SUMENEP)
}

\author{
Adhen Hendra Sukmana', Astri Furqani ${ }^{2}$ \\ ${ }^{1,2,)}$ Fakultas Ekonomi dan Bisnis Universitas Wiraraja \\ Email: adhenhendra07@gmail.com ${ }^{1}$, astri@wiraraja.ac.id ${ }^{2}$
}

\begin{abstract}
ABSTRAK
Konsep materialitas menjadi hal yang penting dalam setiap proses reviu Laporan Keuangan Pemerintah Daerah (LKPD). Hal tersebut untuk memberikan keyakinan terbatas bahwa tidak ada perubahan atau modifikasi salah saji material yang dilakukan agar laporan keuangan tersebut sesuai dengan standar akuntansi pemerintah. Penelitian ini bertujuan untuk mengetahui bagaimana konsep materialitas dalam perspektif auditor Inspektorat Sumenep. Penelitian ini menggunakan Pendekatan kualitatif metode studi kasus deskriptif dengan objek penelitian di Inspektorat Kabupaten Sumenep. Pengumpulan data melalui observasi, wawancara, dan dokumentasi. Informan kunci dalam penelitian ini adalah pengendali teknis ketua tim reviu LKPD, dikarenakan kedua informan tersebut dianggap paling mengetahui terkait materialitas laporan keuangan. Hasil penelitian menunjukkan bahwa konsep materialitas dalam perspektif auditor Inspektorat Sumenep cukup baik dilaksanakan. Pendekatan konsep materialitas tercermin dalam proses pelaksanaan reviu LKPD yang terdiri dari pertimbangan awal tentang materialitas salah saji laporan keuangan, materialitas salah saji pada tingkat laporan keuangan, materialitas salah saji pada tingkat saldo akun, dan alokasi materialitas pada tingkat saldo akun. Namun pada pendekatan alokasi materialitas pada tingkat saldo akun dilakukan secara sederhana dengan sistem pendekatan terhadap salah saji yang terdapat dilaporan keuangan karena terkait dengan tugas dan fungsi Inspektorat sebagai APIP yang hanya melakukan reviu terbatas dan tidak mengeluarkan opini.
\end{abstract}

Kata Kunci: Materialitas, Standar Akuntansi Pemerintah, Inspektorat, LKPD

\section{INTRODUCTION}

Harapan masyarakat sangat besar perihal terbentuknya good corporate governance dan pengelolaan organisasi sektor publik yang efektif, efisien, transparan, bertanggungjawab serta bersih dan lepas dari praktik korupsi, intrik, dan nepotisme membutuhkan peningkatan peran dari pengawasan internal. Tata kelola pemerintahan yang baik (good governance) tidak semata-mata ditujukan bagi pemerintahan pusat namun pemerintahan daerah juga diminta untuk melaksanakan good governanceagar tercipta tata kelola pemerintahan yang baik di setiap garis atau lini pemerintahan.

Terdapat salah satu contoh kasus dimana kinerja atau peran Inspektorat dipertanyakan sebagai audit internal pemerintah, yaitu kasus korupsi yang dilakukan oleh seorang Bupati di kabupaten Bangkalan Madura. Semasa menjabat Bupati hingga ditangkap KPK pada akhir tahun 2014, yang bersangkutan melakukan korupsi dan pencucian uang ratusan miliar. Bupati tersebut mengutip beberapa persen dari APBN yang mengucur ke setiap SKPD (https://m.detik.com, 2018). Berdasarkan contoh kasus di atas dapat ditarik sebuah 
asumsi dasar yaitu tingkat profesionalisme dan etika Inspektorat Daerah cukup rendah.

Pelaksanaan audit internal pemerintahan di Indonesia saat ini masih belum terlaksana dengan baik, salah satunya disebabkan oleh rendahnya kapabilitas APIP. Rendahnya kapabilitas Inspektorat di daerah salah satunya tercermin dari Penilaian Komisi Pemberantasan Korupsi bahwa kasus korupsi di sejumlah daerah terjadi karena APIP tidak diberdayakan (www.kompas.com). Rendahnya Kapabilitas APIP juga dapat dilihat dari masih sedikitnya Inspektorat Daerah yang memperoleh predikat Level 3 Kapabilitas APIP.

Peranan etika dalam profesi auditor, audit membutuhkan pengabdian yang besar pada masyarakat dan komitmen moral yang tinggi. Terdapat kode etik APIP telah diatur dalam Keputusan Dewan Pengurus Nasional Asosiasi Auditor Intern Pemerintah Indonesia (DPN AAIPI) Nomor: KEP005/AAIPI/DPN/2014 Tentang Pemberlakuan Kode Etik Auditor Intern Pemerintah Indonesia, Standar Audit Intern Pemerintah Indonesia, Dan Pedoman Telaah Sejawat Auditor Intern Pemerintah Indonesia. sebagaimana yang telah diatur dalam peraturan tersebut, wajib dipergunakan sebagai acuan untuk mencegah terjadinya tingkah laku yang tidak etis sehingga terwujud auditor yang kredibel dengan kinerja yang optimal dalam pelaksanaan audit. Apalagi jika kaitannya dengan Laporan Keuangan Pemerintah Daerah (LKPD). Auditor harus memperoleh pemahaman yang cukup mengenai entitas serta konsep materialitas, termasuk pengendalian internal untuk menilai risiko salah saji material dalam laporan keuangan karena kesalahan atau kecurangan, dan untuk merancang sifat, waktu serta luas prosedur audit selanjutnya. Karena Laporan Keuangan Pemerintah Daerah (LKPD) sangat riskan mengalami kecurangan baik dari kelompok tertentu maupun individunya.

Pemerintahan di Kabupaten Sumenep, terdapat fakta yang menyebutkan bahwa untuk kali pertama Pemerintah Kabupaten Sumenep meraih opini Wajar Tanpa Pengecualian (WTP) dari Badan Pemeriksa Keuangan (BPK) RI. Prestasi itu diraih berdasarkan pemeriksaan atas Laporan Keuangan Pemerintah Daerah (LKPD) Kabupaten Sumenep tahun anggaran 2017 sampai dengan 2019.

Berdasarkan fakta diatas, prestasi Pemerintah Kabupaten Sumenep dalam meraih opini Wajar Tanpa Pengeculian (WTP) tidak terlepas dari peran Inspektorat sebagai lembaga audit internal pemerintah yang mempunyai andil besar terhadap tercapainya Pemerintah Kabupaten Sumenep mendapatkan opini Wajar Tanpa Pengecualian (WTP) oleh BPK-RI Jawa Timur. Salah satu andil Inspektorat dalam menciptakan pemerintahanyang baik adalah menetapkan tingkat materialitas dalam melaksanakan kegiatan audit melalui konsep materialitas pada Laporan Keuangan Pemerintatah Daerah (LKPD) menurut auditor yang bekerja di Inspektorat Sumenep.Dalam melaksanakan tugas, penting bagi auditor Inspektorat untuk menetapkan pertimbangan awal materialitas dalam menentukan tingkat materialitas. 


\section{LITERATURE REVIEW}

\section{Konsep Materialitas}

Informasi dipandang sebagai material bila disajikan salah atau tidak disajikan dapat mempengaruhi kepautusan-keputusan ekonomis yang diambil oleh pengguna laporan yang mendasarkan keputusankeputusannya sebagian pada informasi dalam laporan keuangan (Murwanto, Budiarso, \& Ramadhana, 2008:150).

\section{Pentingnya Konsep Materialitas Salah Saji} Dalam Audit atas Laporan Keuangan

Dalam audit atas laporan keuangan, auditor tidak dapat memberikan jaminan bagi klien atau pemakai laporan keuangan yang lain, bahwa laporan keuangan auditor adalah akurat. Auditor tidak dapat memberikan jaminan karena ia tidak memeriksa setiap transaksi yang terjadi dalam tahun yang diaudit dan tidak dapat menentukan apakah semua transaksi yang terjadi telah dicatat, diringkas, digolongkan, dan dikompilasi secara semestinya ke dalam laporan keuangan. Jika auditor diharuskan untuk memberikan jaminan mengenai keakuratan laporan keuangan auditan, hal ini tidak mungkin dilakukan, karena akan memerlukan waktu dan biaya yang jauh melebihi manfaat yang dihasilkan (Mulyadi, 2002:159).

\section{Indikator Konsep Materialitas}

Terdapat beberapa indikator konsep materialitas yang dilakukan seorang auditor terhadap laporan keuangan untuk menentukan seberapa besar salah saji dalam suatu laporan keuangan, yaitu menurut (Mulyadi, 2002:159) sebagai berikut:

1) Pertimbangan awal tentang materialitas salah saji laporan keuangan.

Auditor melakukan pertimbangan awal tentang tingkat materialitas salah saji dalam perencanaan auditnya. Penentuan materialitas ini, yang seringkali disebut dengan materialitas perencanaan, mungkin dapat berbeda dengan tingkat materialitas yang digunakan pada saat pengambilan kesimpulan audit dan dalam mengevaluasi temuan audit karena (1) keadaaan yang melingkupi berubah, (2) informasi tambahan tentang klien dapat diperoleh selama berlangsungnya audit. Sebagai contoh, klien mungkin dapat memperoleh sumber pembelanjaan untuk melanjutkan usahanya, yang pada saat audit direncanakan auditor meragukan kemampuan klien dalam mempertahankan kelangsungan hidup usahanya. Kemudian, audit yang telah dilaksanakan dapat memastikan bahwa karena sumber pembelanjaan tersebut, solvabilitas klien dalam periode yang diaudit telah mengalami peningkatan secara signifikan. Dalam keadaan ini, tingkat audit dapat lebih tinggi dibandingkan dengan materialitas salah saji perencanaan(Mulyadi, 2002:159).

2) Materialitas salah saji pada tingkat laporan keuangan.

Dalam menerapkan materialitas, ada dua cara yang perlu diperhatikan auditor. Cara pertama, auditor membuat materialitas pada saat perencanaan audit. Cara kedua, melakukan pengevaluasian bukti audit pada saat pelaksanaan audit. Dalam pelaksanaan audit, penting bagi auditor melakukan perhitungan materialitas karena terdapat korelasi utama antara jumlah laporan keuangan dalam bentuk fisik (uang) dipandang material dengan auditor dengan kuantitas pekerjaan audit yang dimaksudkan untuk membuktikan kewajaran laporan keuangan (Mulyadi, 2002:159).

3) Materialitas salah saji pada tingkat saldo akun. 
Kendatipun auditor memberikan pendapat atas laporan keuangan secara menyeluruh, namun ia harus melakukan pemeriksaan terhadap akun-akun secara tersendiri dalam mengumpulkan bukti audit yang digunakan sebagai dasar untuk menyatakan pendapatnya atas laporan keuangan audit. Maka dari itu, perhitungan materialitas salah saji yang dibuat pada tahap perencanaan audit harus didistribusikan ke masing-masing akun laporan keuangan secara individual yang akan diperiksa elemen materialitas salah saji yang dialokasikan ke masing-masing akun secara individual, ini dikenal dengan sebutan salah saji yang dapat diterima untuk akun tertentu (Mulyadi, 2002:159).

4) Alokasi materialitas pada tingkat saldo akun.

Bila pertimbangan awal auditor tentang materialitas salah saji laporan keuangan dikuantifikasikan penaksiran awal tentang materialitas salah saji untuk setiap akun dapat diperoleh dengan mengalokasikan materialitas salah saji laporan keuangan ke akun secara individual. Pengalokasian ini dapat dilakukan baik untuk akun neraca maupun akun laba-rugi. Namun, karena hampir semua salah saji laporan laba-rugi juga mempengaruhi neraca dan karena akun neraca lebih sedikit banyak auditor yang melakukan alokasi atas dasar akun neraca. Dalam melakukan alokasi, auditor harus mempertimbangkan kemungkinan terjadinya salah saji dalam akun tertentu dengan biaya yang harus dikeluarkan untuk memverifikasi akun tersebut (Mulyadi, 2002:159).

\section{Internal Auditor}

Internal Auditor harus mengetahui resiko kunci organisasi untuk memberikan masukan/arahan dan memberikan keyakinan kepada pihak manajemen. Dengan demikian Internal auditor harus dapat memberikan kontribusi untuk meningkatkan kinerja dan harus proaktif dalam menjalin komunikasi dengan pihak manajemen. Internal auditor harus memiliki kemampuan yang dapat memenuhi kebutuhan organisasi dan dapat bekerja lebih cerdas dan mampu memanfaatkan kemajuan teknologi.

\section{Reviu}

Reviu secara umum didefinisikan sebagai kegiatan meninjau kembali apa yang telah dilakukan/diputuskan sebelumnya baik mengenai kebijakan, strategi, perencanaan maupun pelaksanaan, untuk mengetahui sejauhmana kebijakan, strategi, perencanaan, dan pelaksanaan tersebut telah memenuhi standar yang ditetapkan.

\section{METHODS}

Penelitian ini akan menggambarkan bagaimana konsep materialitas dalam perspektif auditor Inspektorat Sumenep. Penelitian ini menggunakan pendekatan kualitatif. Peneliti menggunakan metode kualitatif karena ingin menggali informasi dari para informan secara mendalam mengenai konsep materialitas dalam perspektif auditor Inspektorat Kabupaten Sumenep.(Moleong, 2007).

Penelitian ini dilakukan di Inspektorat Sumenep. alasan memilih lokasi tersebut karena Inspektorat Sumenep merupakan lembaga audit internal pemerintah dibawah perintah langsung dari Bupati Kabupaten Sumenepyang mempunyai fungsi sebagai pengawas, audit, review, pemantauan, serta evaluasi terhadap seluruh pemerintahan daerah. Waktu penelitian ini dilakukan pada saat pengerjaan proposal penelitian dari bulan februari hingga juli. 
Jenis data dalam penelitian ini menggunakan data subjek yang artinya data bersumber dari responden atau informan. Sumber data penelitian ini menggunakan data primer, yang diperoleh langsung dari hasil wawancara mendalam dengan narasumber di Inspektorat Sumenep.

Yang menjadi informan kunci dalam penelitian ini adalah pengendali teknis reviu LKPD Inspektorat Sumenep bapak dengan inisial A.F dan ketua tim audit reviu LKPD ibu dengan inisial S. K.

Peneliti menghimpun dan mencari informasi secara relevan dengan apa yang dimaksudkan dalam ruang lingkup penelitian melalui Observasi, Wawancara dan Dokumentasi. Observasi dilakukan dengan pengamatan langsung di Inspektorat Sumenep. Wawancara dilakukan terhadap pengendali teknis reviu dan Ketua tim reviu LKPD. Wawancara dilakukan pada tempat dan waktu yang berbeda, sesuai dengan waktu yang diberikan informan. Dokumentasi dilakukan dengan melakukan kajian atas dokumen-dokumen yang ada.

Teknik analisis data dalam penelitian ini menggunakan analisis deskriptif. Menurut (Sugiyono, 2014:53) menjelaskan bahwa data yang diperoleh secara menyeluruh nantinya akan dianalisis dan disajikan secara deskripsi, yaitu dengan menggambarkan, meringkaskan, dan menjelaskan apa saja mengenai konsep materialitas dalam perspektif auditor Inspektorat.

Reduksi data dilakukan oleh peneliti bersamaan dengan proses pengumpulan data. Mempertimbangkan bahwa reduksi data ini terjadi secara beulang-ulang dan jika ditemukan data yang tidak sesuai, nantinya peneliti melakukan pengecekan kembali untuk memperoleh kevalidan data dalam menjelaskan fokus penelitian. Reduksi data dalam penelitian ini adalah dengan melakukan catatan tertulis yang diperoleh dilapangan oleh peneliti dari hasil observasi dan wawancara mendalam dengan para narasumber terkait di Inspektorat Sumenep.

Penyajian data ini dilakukan agar hasil reduksi data dapat disempurnakan, diorganisir, dan disusun secara sistematis, sederhana, dan kompleks. Sehingga mudah untuk dipahami dengan apa yang terjadi dilapangan, dan merencanakan kerja penelitian selanjutnya.

Verifikasi merupakan langkah pemantapan dari sebuah penelitian lapangan yaitu menarik kesimpulan berdasarkan hasil temuan yang diperoleh dan juga melakukan verifikasi data. Kesimpulan awal yang diuraikan peneliti bersifat sementara dan tidak menutup kemungkinan akan berubah bila ditemukan bukti yang kuat, yang dapat mendukung pengumpulan data selanjutnya.

Untuk memperoleh keabsahan data diperlukan triangulasi. Maleong (2007:330) menjelaskan bahwa triangulasi ini merupakan teknik pemeriksaan keabsahan data yang memanfaatkan sesuatu yang lain di luar data untuk keperluan pengecekan terhadap data yang ada. Keabsahan data peneliti menggunakan triangulasi dengan sumber, yang fungsinya adalah untuk membandingkan dan mengecek kepercayaan dari suatu informasi yang akan diperoleh. Penelitian ini membandingkan data dari hasil observasi dengan wawancara. 


\section{RESULT AND DISCUSSION}

\section{Pertimbangan Awal Tentang Materialitas Salah Saji Laporan Keuangan}

Pertimbangan awal tentang materialitas salah saji laporan keuangan merupakan salah satu indikator konsep materialitas, penentuan materialitas ini biasanya dilakukan pada tahap perencanaan yang bertujuan agar pereviu laporan keuangan mempunyai pandangan awal tentang pertimbangan awal materialitas tersebut. Auditor menentukan pertimbangan awal materialitas juga untuk membantu perancangan pengumpulan bukti audit. Pertimbangan awal materialitas diawali berdasarkan saat pengambilan kesimpulan audit dan untuk mengevaluasi temuan audit. Berdasarkan hasil penelitian reviu LKPD Inspektorat Sumenep dalam penerapan pertimbangan awal materialitas terdapat beberapa hal yang dilakukan, yaitu sebagai berikut:

1. Pertimbangan awal materialitas yang dilakukan yaitu dengan melihat konsistensi setiap akun yang ada dilaporan keuangan, tentunya yang berhubungan dan berkaitan antara akun-akun tersebut, Jadi seberapa besar pada akun tersebutakan berpenigaruh secara signifikan terhadap akun-akun yang lain.

2. Apabila terdapat salah saji dalam laporan keuangan, apabila salah saji tersebut mempengaruhi terhadap akun bagan atau akun standarnya maka itu dikatakan sebagai materialitas pada tim reviu.

3. Dan human error, terdapat kesalahan dalam penyajian informasi akuntansi yang dilakukan oleh beberapa organisasi perangkat daerah (OPD) sehingga ini juga merupakan pertimbangan awal menetapkan materialitas yang dilakukan oleh reviu LKPD Inspektorat Sumenep.
4. Apabila terdapat salah saji material yang signifikan, harus diungkapkan secara utuh/komprehensif didalam catatan atas laporan keuangan agar tidak menyesatkan bagi pembaca laporan keuangan tersebut. Jika salah saji tersebut tidak bisa diperbaiki, tidak menjadi masalah karena laporan keuangan tersebut harus dilaporkan ke BPK-RI dengan catatan CALKnya menyebutkan salah saji material yang signifikan tersebut.

Hal tersebut di atas dapat dilihat dari hasil wawancara dengan salah satu informan, yang dilakukan kepada bapak A.F selaku pengendali teknis, beliau mengatakan:

"Pertimbangan awal itu kita akan mencoba konsistensi setiap akun yang ada dilaporan keuangan, tentunya yang berhubungan dan berkaitan antar akun-akun tersebut. Contoh pertimbangan awal kita, kita harus memahami konsep awal analisisnya. Kalau itu adalah LRA itu kaitannya pada akun apa, misal belanja pegawai, belanja pegawai itu berpengaruh pada apa analisisnya ? berpengaruh pada neraca, kita kroscek di neraca ketika ada selisih salah saji, kita tidak serta merta merubah pada laporan keuangan tersebut, paling tidak kita komunikasikan kepada bidang akuntansi di BPPKAD itu untuk merubah termasuk didalamnya kita membuat jurnal koreksi, ketika memang ada salah saji material". (Hasil wawancara tanggal 06-04-2019)

Lebih lanjut bapak A. F juga menjelaskan bahwa:

“Apabila terdapat salah saji material yang signifikan, maka pertimbangan-pertimbangan itu baru kita pada rujukan seterusnya kepada aspek materialitasnya itu sendiri, sekiranya itu memang ada selisih dan tidak bisa dijelaskan oleh bidang akuntansi dalam hal ini pembuat LKPD, susah itu misalkan untuk dijelaskan, tidak masalah tetapi paling tidak itu diungkapkan secara utuh/komprehensif 
didalam catatan atas laporan keuangan (CALK) jadi biar tidak menyesatkan kepada pembaca laporan keuangan itu. andai selisih itu tidak bisa entitas akuntansinya tidak bisa merubah, tidak apa-apa tapi paling tidak itu laporan jalan terus tetapi CALK-nya menyebutkan atas selisih itu, karena laporan tersebut harus dilaporkan ke BPK-RI sesuai dengan waktu yang ditentukan." (Hasil wawancara tanggal 06-04-2019)

\section{Adapula pertimbangan yang diklasifikasikan menjadi 2 yaitu} pertimbangan kuantitatif dan pertimbangan kualitatif. Pertimbangan kuantitatif kaitannya jumlah kunci tertentu dalam laporan keuangan berhubungan dengan salah saji yang ditemukan, sedangkan pertimbangan kualitatif ini berkaitan apa penyeba terjadinya salah saji atau bisa dikatakan sebagai alasannya. Apabila ditemukan terdapat salah saji dalam bentuk kuantitatif maka hal tersebut harus dijelaskan dalam bentuk kualitatif atau penyebab timbulnya salah saji pada laporan keuangan.

Dalam penelitian ini dimana juga dibahas mengenai pertimbangan secara kuantitatif dan kualitatif, dari hasil penelitian yang dilakukan pada objek penelitian yaitu reviu LKPD Inspektorat Sumenep diketahui pertimbangan secara kuantitatif dan kualitatif menurut reviu LKPD Inspektorat Sumenep, yaitu:

1. Perimbangan awal materialitas secara kuantitatif, aspek kesalahan atau aspek materialitas atas kesalahan penyajian informasi akuntansi berapapun jumlahnya dimasukkan dalam temuan reviu LKPD Inspektorat dan diberikan rekomendasi untuk dikembalikan, adapun hal lain yang menjadi pertimbangan awal materialitas secara kuantatif adalah peraturan Bupati Kabupaten Sumenep tentang kebijakan akuntansi.
2. Pertimbangan awal materialitas secara kualitatif, misalkan Rp150,00 secara kuantitatif tidak material lainnya halnya dengan secara kualitatif yang melihat penyebab tersebut, biasanya dapat dilihat dalam bentuk sistem pengendalian intern (SPI) jadi temuan tersebut menjadi material karena adanya kelemahan atas mekanisme, prosedur, alur dalam proses pelaporan keuangannya.

Kedua pertimbangan tersebut sesuai dengan pernyataan bapak A.F selaku pengendali teknis reviu LKPD

Hasil penelitian telah memaparkan apa saja yang menjadi bentuk pertimbangan awal materialitas salah saji pada laporan keuangan itu sendiri. Bentuk pertimbangan awal materialitas yang dilakukan adalah pada saat perencanaan audit atau pada saat proses pelaksanaan reviu LKPD, reviu LKPD terlebih dahulu melihat atau menelaah atas beberapa akun LKPD seperti akun laporan realisasi anggaran (LRA), akun neraca, catatan atas laporan keuangan (CALK). Hal tersebut dilakukan untuk mengetahui hubungan antar akun-akun laporan keuangan serta salah saji yang terdapat pada akun-akun tersebut apakah berpengaruh signifikan atau tidak. Setelah itu reviu LKPD melakukan identifikasi permasalahan pada proses penyajian informasi akuntansi (LKPD). Hal tersebut dilakukan guna untuk membantu auditor/pereviu merencanakan dan mengumpulkan bahan bukti yang cukup.

\section{Materialitas Salah Saji Pada Tingkat Laporan Keuangan}

Dalam menilai tingkat kualitas suatu laporan keuangan diperlukan sebuah penaksiran materialitas pada saat perencanaan auditor benar-benar harus mempertimbangkannya dengan baik. 
Andaikata auditor menentukan jumlah materialitas tinggi maka nantinya auditor cenderung mengabaikan salah saji yang berpengaruh signifikan dengan memberikan pendapat untuk laporan keuangan yang kenyataannya terdapat salah saji.

Berdasarkan hasil penelitian, ada 2 cara yang patut diperhatikan oleh auditor untuk menentukan materialitas salah saji pada tingkat laporan keuangan. Cara pertama auditor membuat materialitas pada saat perencanaan audit, dalam hal ini reviu LKPD Inspektorat melakukannya bersamaan pada proses pelaksanaan reviu karena pada proses pelaksanaan reviu, reviu juga akan mengkroscek laporan keuangan serta mengidentifikasi masalah yang ada dilaporan keuangan, jadi hal tersebut dapat diketahui apabila laporan keuangan tersebut mengandung salah saji material yang berdampak signifikan secara individu atau secara gabungan. Cara yang terakhir atau kedua adalah auditor melakukan pengevaluasian bukti audit, dalam hal ini reviu LKPD Inspektorat melakukannya dengan mempertimbangkan bukti-bukti yang diketahui dari hasil temuan BPK pada tahun sebelumnya serta melakukan koordinasi dengan penyusun laporan keuangan atau BPPKAD, koordinasi ini dilakukan untuk menentukan unit akuntansi dan akun signifikan yang akan direviu, dan juga prosedur reviu yang akan digunakan berdasarkan pada penilaian resiko kesalahan dalam mencatat transaksi keuangan dan kelemahan proses pelaporan keuangan.

Berdasarkan penjelasan diatas juga dapat dilihat dari hasil wawancara yang dilakukan oleh salah satu informan yaitu Ibu S. K selaku ketua tim reviu LKPD, beliau mengatakan:

"Hal yang pertama kita kan pasti menetapkan PKR nya (program kerja reviu) nya pembagian antara neraca LRA, LO programprogram kerja yang akan ditelusuri disana, setiap tahun itu keluar peraturan peraturan menteri jadi ada ada Permendagri tentang proses pelaksanaan reviu laporan keuangan pemerintah daerah ini sudah ada panduan formal dari pemerintah pusat Bagaimana tata cara langkah yang digunakan dalam proses reviu, langkah pertama yang pasti kita bikin PKR dulu program kerja pemeriksaan pelaksanaan reviu. Banyak hal yang dinilai disana didalamnya termasuk adalah SPI ( Sistem Pengendalian Internal. Jadi kita akan melakukan penilaian atas SPI nya, jadi kita tetapkan dulu dari SPI itu bagaimana kita menelaah setiap prosedur untuk memastikan bahwa pada saat pelaksanaan reviu, kita dapat mengkroscek setiap akun yang ada dilaporan keuangan". (Hasil wawancara tanggal 16-04-2019)

Dalam menerapkan materialitas pada tingkat laporan keuangan diperlukan juga pengevaluasian bukti audit pada saat pelaksanaan audit. Hal ini dibenarkan oleh informan pengendali teknis reviu, bapak A. F yang mengatakan:

"Untuk pengevaluasian bukti audit, kita akan pelajari dulu hasil temuan BPK atas LKPD pada tahun sebelumnya, nantinya kita akan melakukan koordinasi dengan penyusun LKPD dalam hal ini BPPKAD, koordinasi ini dilakukan untuk menentukan unit akuntansi dan akun signifikan yang akan direviu, dan juga prosedur reviu yang akan digunakan berdasarkan pada penilaian resiko kesalahan dalam mencatat transaksi keuangan dan kelemahan proses pelaporan keuangan". (Hasil wawancara tanggal 06-04-2019)

Adapun hubungan materialitas dengan bukti audit yaitu bukti audit itu dijadikan sebagai dasar untuk menentukan tingkat materialitas. Selanjutnya setelah rekapan bukti audit terkumpul tim reviu melakukan penelusuran lebih lanjut sampai pada bukti 
pertanggungjawaban jika ada indikasi salah saji material yang sangat signifikan, biasanya salah saji yang signifikan tersebut salah satunya adalah penyajian akun.

\section{Materialitas Salah Saji Pada Tingkat Saldo Akun}

Berdasarkan hasil penelitian yang dilakukan pada reviu LKPD Inspektorat Sumenep dalam pemeriksaan akun-akun laporan keuangan, yang menjadi konsen atau yang menjadi perhatian utama auditor Inspektorat adalah neraca, karena apabila terjadi materialitas salah saji dineraca pengaruhnya terhadap laporan keuangan lainnya, seperti LO, LRA, dan CALK. Jadi apabila OPD telah merealisasikan anggarannya untuk kegiatan tertentu, nominal anggaran tersebut disajikan dengan benar pada neraca, belum tentu pada laporan keuangan yang lain seperti LO, LRA, dan CALK nya sesuai nominal anggarannya yang dicantumkan pada laporan keuangan neraca, maka dari itu yang menyebabkan salah saji pada akun-akun neraca biasanya diakibatkan karena proses penyajian informasi akuntansi yang salah yang meliputi proses perhitungan, penjumlahan, pengurangan, dan lain sebagainya. Hal tersebut sesuai dengan hasil wawancara dengan Ibu S. K.

Dalam mempertimbangkan salah saji pada tingkat saldo akun, auditor harus memperhatikan dan mempertimbangkan hubungan materialitas salah saji pada tingkat laporan keuangan dengan materialitas salahsaji pada tingkat saldo akun. Mempertimbangkan hubungan tersebut dilakukan guna mendeteksi salah saji material secara individual, dapat material terhadap laporan keuangan secara keseluruhan apabila digabungkan dengan salah saji dalam saldo akun yang lain.

Demikian juga auditor harus mempertimbangkan hubungan antara materialitas pada saldo akun dengan materialitas pada laporan keuangan fungsinya untuk mendeteksi salah saji yang kemungkinan tidak material secara individual. Hal ini didukung dengan pernyataan bapak A.F sebagai pereviu Inspektorat Sumenep yang mengatakan:

"Materialitas tingkat saldo akun dan tingkat laporan keuangan itu ada hubungannya. Jadi saldo akunnya di entitas akuntansi itu harus sama dengan apa yang disajikan dilaporan keuangan, makanya BPPKAD itu fungsinya adalah melakukan pengkonsolidasian antara entitas akuntansi dengan entitas pelaporan, entitas akuntansinya kan dari OPD, entitas pelaporan dari BPPKAD bidang akuntansi. Benar tidak akun2 yang di tampilakan entitas akuntansi muncul dalam laporan keuangan, kalau mereka sudah melacaknya tinggal melihat LRA nya." (Hasil wawancara tanggal 06-04-2019)

Berdasarkan hasil penelitian dan persepsi reviu LKPD Inspektorat Sumenep hubungan tersebut pertimbangannya apabila salah saji saldo akun tingkat materialitasnya tinggilaporan keuangannya tidak akan valid, jadi apabila terjadi salah saji pada saldo akun tentu pengaruhnya pada laporan keuangan atau laporan yang lainnya. 
Alokasi Materialitas Pada Tingkat Saldo Akun

Dalam penerapan indikator alokasi materialitas salah saji pada saldo akun diperlukan pertimbangan awal materialitas salah saji laporan keuangan yang dikuantifikasikan taksiran awal tentang materialitas salah saji pada setiap akun dapat diperoleh dengan mengalokasikan materialitas salah saji laporan keuangan keseluruhan ke akun secara individual. Dalam melakukan hal tersebut auditor diharuskan mempertimbangkan terjadinya salah saji dalam akun tertentu dengan biaya yang dikeluarkan untuk mengkonfirmasi akun tersebut.

Berdasarkan hasil wawancara yang dilakukan kepada bapak A. F yang menjelaskan tentang alokasi materialitas, beliau mengatakan bahwa:

"Atas materialitas itu sendiri, ada di dalam kebijakan akuntansi yang di susun dalam peraturan Bupati. Berapa sih nilai materialitas itu sendiri ?itu ada di kebijakan akuntansi, misal atas aset, berapa yang bisa diakui sebagai alokasi materialitas itu di kebijakan akuntansi, berapa nilai aset yang bisa diakui sebagai nilai aset. Dan juga tidak ada biaya untuk melakukan verifikasi akun2 yang materialitas. karena memang kaitannya kepada tugas, fungsi, dan kewenangan bidang akuntansi. Kalau memang ada salah saji, kalau masih bisa dirubah, ubah dari bawah. maka nya disitu ada arena konsolidasian untuk mengkroscek itu semua" (Hasil wawancara tanggal 06-04-2019).

Berdasarkan penelitian yang dilakukan pada reviu LKPD Inspektorat Sumenep tidak ada biaya verifikasi dalam melakukan alokasi materialitas dikarenakan terkait dengan tugas, fungsi, dan kewenangan bidang akuntansi, reviu melakukannya secara sukarela. Jadi apabila terjadi salah saji materialitas pada akun-akun tertentu reviu Inspektorat melakukan pemeriksaannya secara sukarela demi tercapainya tujuan dari lembaga Inspektorat Sumenep sendiri.

Menurut penulis dalam menentukan alokasi materialitas salah saji pada tingkat laporan keuangan maupun tingkat saldo akun, reviu melakukannya dengan baik dan sesuai dengan aturan / pedoman yang berlaku dalam pelaksanaan reviu. Dan juga bisa diterima apabila auditor / pereviu melaksanakan hal tersebut tanpa dibayar karena kaitannya dengan tugas, fungsi, dan wewenang dibidang akuntansi.

\section{Analisis Konsep Materialitas Dalam Perspektif Auditor Inspektorat Sumenep}

Terdapat beberapa pendekatan yang dinilai sebagai suatu kewajiban dalam menentukan konsep materialitas pada laporan keuangan yang dilakukan oleh tm reviu LKPD Inspektorat Sumenep . Pendekatan tersebut nantinya akan menilai sejauh mana informasi dipandang material atau tidak disajikan dapat mempengaruhi keputusankeputusan ekonomi yang diambil oleh pengguna laporan keuangan. Pendekatan yang dimaksud adalah proses pelaksanaan reviu yang mencakup penelaah atas akun laporan realisasi anggaran (LRA), akun neraca, catatan atas laporan keuangan (CALK), dan proses pelaporan keuangan pada unit akuntansi kuasa pengguna anggaran (UAKPA) dan unit akuntansi terkait lainnya, serta penyusunan kertas kerja reviu (KKR) dan catatan hasil reviu (CHR). pelaksanaan reviu tersebut nantinya dikoordinasikan dengan penyusun laporan keuangan LKPD dalam hal ini BPPKAD. Hal ini diperlukan untuk melakukan pembahasan mengenai komunikasi atas rencana pelaksanaan kepada unit-unit vertical, pembahasan hasil reviu dan penyelesaian masalah pada tingkat kebijakan. Tahapan pelaksanaan reviu ini meliputi identifikasi permasalahan pada proses 
penyelenggaraan akuntansi dan penyajian LKPD serta pemberian saran perbaikan dan bantuan kepada unit akuntansi agar segera memperbaiki kesalahan dan kelemahan yang terjadi pada laporan keuangan tersebut

Berdasarkan hasil penelitian menunjukkan bahwa dari upaya meningkatkan laporan keuangan dengan menganalisis salah saji informasi akuntansi yang ada pada tim reviu LKPD Inspektorat Sumenep telah menunjukkan bahwa pada tim reviu LKPD Inspektorat Sumenep telah mengacu pada pendekatan konsep materialitas, meskipun dalam pelaksanaannya tidak semua aspekaspek yang ada dalam pendekatan konsep materialitas mampu terwujud. Hal tersebut karena adanya beberapa masalah yang terjadi seperti perbedaan pemahaman atau versi mengenai materialitas yang pada dasarnya konsep materialitas dipraktekkan oleh auditor internal perusahaan maupun pamerintah dalam hal ini (BPK-RI), jadi terjadi perbedaan persepsi mengenai materialitas tersebut.

\section{CONCLUSION}

Berdasarkan hasil penelitian dan analisis yang dilakukan oleh peneliti, maka peneliti menyimpulkan sebagai berikut:

Penentuan materialitas salah saji pada laporan keuangan, Tim reviu Inspektorat Sumenep pertimbangan awalnya yaitu melakukan pemahaman terlebih dahulu mengenai konsep awal analisis materialitasnya dengan melibatkan BPPKAD atau pihak pembuat laporan keuangan untuk mengetahui tingkat keakuratan suatu laporan keuangan, laporan keuangan juga ditentukan oleh besarnya materialitas yang ada di laporan keuangan pada saat awal perencanaan dalam pembahasan pembuatan KKR (Kertas Kerja Reviu) telah disepakati berapa tingkat materialitas nya dengan batasan-batasan tertentu yang disepakati oleh dalam proses perencanaan auditor.Materialitas salah saji pada tingkat laporan keuangan juga dilakukan untuk membuktikan kewajaran laporan keuangan dengan merencanakan audit dan melakukan pengevaluasian bukti audit dengan mempelajari hasil temuan dari BPK pada tahun sebelumnya serta berkoordinasi dengan penyusus laporan keuangan (BPPKAD) untukmenentukan unit akuntansi dan akun signifikan yang akan direviu, dan juga prosedur reviu yang akan digunakan berdasarkan pada penilaian resiko kesalahan dalam mencatat transaksi keuangan dan kelemahan proses pelaporan keuangan.

Materialitas salah saji pada tingkat saldo akun, tim reviu Inspektorat Sumenep melakukan kroscek Kertas Kerja Reviu (KKR) dan membandingkannya dengan BPPKAD atau pembuat laporan keuangan, juga penelusuran secara rinci yang dimulai dari SP2D (Surat Perintah Pencarian Dana) dan SPP (Surat Permintaan Pembayaran). Dan pemeriksaan akun-akun yang terdapat di neraca serta mempertimbangkan risiko yang lebih tinggi untuk diutamakan pemeriksaannya. karena apabila salah saji material terdapat disaldo akun neraca nantinya akan berpengaruh terhadap laporan keuangan secara keseluruhan, seperti LO, LRA dan juga CALK. Auditor/pereviu Inspektorat juga melihat materialitas pada laporan keuangan atau masing-masing akun dilaporan keuangan juga dengan Peraturan Bupati Sumenep No. 90 Tahun 2018 Tentang Kebijakan Akuntansi Pemerintah Sumenep. Maksudnya adalah apabila penyajian laporan akuntansi tidak sesuai dengan Peraturan Bupati Sumenep maka dapat dikatakan laporan keuangan tersebut mengandung materialitas.Alokasi materialitas pada tingkat saldo akun belum dilakukan perhitungan alokasi materialitas secara jelas, karena dalam 
alokasi materialitas dibutuhkan biaya untuk melakukan alokasi materialitas masingmasing akun tersebut. Sedangkan di Inspektorat tidak membutuhkan atau menarik biaya dalam melakukan alokasi materialitas karena kaitannya dengan tugas dan fungsi auditor pemerintah. Inspektorat sebagai APIP perannya hanyasebatas melakukan reviu LKPD, bukan melakukan audit yang mendalam apalagi sampai mengeluarkan opini seperti BPK.

Dari hasil penelitian serta analisis dan pembahasan yang telah disimpulkan diatas, maka peneliti memiliki saran hendaknya Tim Reviu dalam suatu proses penentuan konsep materialitas salah satunya alokasi materialitas pada tingkat saldo akun dilakukan dengan jelas kuantifikasinya atau perhitungan materialitasnya pada tingkat saldo akun agar hal ini mempermudah penaksiran awal tentang materialitas untuk setiap akun laporan keuangan tersebut. Penelitian selanjutnya diharapkan tidak hanya meneliti terkait dengan konsep materialitas, tetapi juga meneliti terkait dengan risiko audit dan strategi atau upaya-upaya auditor Inspektorat untuk meminimalisir kesalahan penyajian informasi akuntansi yang dilakukan OPD (organisasi perangkat daerah). Selain hal tersebut hendaknya kekurangan-kekurangan maupun keterbatasan yang ada pada penelitian ini hendaknya dijadikan pertimbangan bagi penelitian selanjutnya.

\section{REFERENCES}

Adi, A. P. (2012). Pengaruh Profesionalisme Auditor, Etika Profesi, dan Pengalaman Auditor terhadap Pertimbangan Tingkat Materialitas. Jurnal Kajian Dan Pendidikan Akuntansi Indonesia, 1 Nomor 3.

Furqani, A., \& Hafidhah. (2015). Peranan Inspektorat Kabupaten Sumenep Dalam
Mencegah Dan Mendeteksi Fraud Di Dinas Pendidikan Sumenep. Jurnal "PERFORMANCE" Bisnis \& Akuntansi, $5(1)$.

Gelspan, R. (2007). The Heat Is Online. Lake Oswego, Or: Green House Network. Retrieved from the Heat is Online website: http://www.heatisonline.org

Halim, A. (2008). Auditing (Dasar-Dasar Audit Laporan Keuangan) (4th ed.). Yogyakarta: STIM YKPN.

https://m.detik.com. (2018). Retrieved from https://m.detik.com

https://radarmadura.jawapos.com/read/2018/0 6/04/78762/pemkab-sumenep-berhasilraih-opini-wtp-bpk-ri. (2018). Retrieved from

https://radarmadura.jawapos.com/read/2 018/06/04/78762/pemkab-sumenepberhasil-raih-opini-wtp-bpk-ri

Mardiasmo. (2002). Akuntansi Sektor Publik. Yogyakarta : Andi.

Miller-Rushing, A. J., Primack, D., \& Mukunda, S. (2006). Photographs and herbarium specimens as tools to document phonological changes in response to global warming. American Journal of Botany, 93, 1667-1674.

Michaels, P. J., \& Balling, R. C., Jr. (2000).The satanic gases: Clearing the air about global warming. Washington, DC: Cato Institute.

Moleong, L. (2007). Metodelogi Penelitian Kualitatif. Bandung: Remaja Karya.

Mulyadi. (2001). Akuntansi Manajemen (3rd ed.). Jakarta: Salemba Empat.

Mulyadi. (2002). Auditing (6th ed.). Jakarta: Salemba Empat.

Murwanto, R., Budiarso, A., \& Ramadhana, F. H. (2008). Audit sektor publik: Suatu Pengantar Bagi Pembangunan Akuntabilitas Instansi Pemerintah. LPKPAP Depkeu RI: BPPK Departeman Keuangan RI.

Nasution, H. (2012). Pengaruh Beban Kerja, Pengalaman Audit dan Tipe Kepribadian terhadap Skeptisisme Profesional dan Kemampuan Auditor dalam Mendeteksi Kecurangan. Jurnal, 15. 
Journal of Accounting and Financial Issue

ISSN : 2775-4642 (Online)

Volume 2, Nomor 1, Mei 2021

Penjelasan UU Nomor 23 Tahun 2014 tentang Pemerintahan Daerah.

Peraturan Menteri Dalam Negeri Republik Indonesia Nomor 4 Tahun 2018 Tentang Pelaksanaan Reviu Atas Laporan Keuangan Pemerintah Daerah Berbasis Akrual.

Peraturan Menteri Negara Pendayagunaan Aparatur Negara Nomor: PER/05/M.PAN/03/2008 tentang Standar Audit Aparat Pengawas Intern Pemerintah.
Pernyataan Standar Akuntansi Pemerintahan. PP Nomor 12 Tahun 2017. PP Nomor 60 Tahun 2008.

Rahardjo, M. (2017). Studi Kasus Dalam Penelitian Kualitatif Konsep Dan Prosedurnya. Universitas Islam Negeri Maulana Malik Ibrahim Malang.

Sugiyono. (2014). Metode Penelitian Kuantitatif, Kualitatif dan $R \& D$. Bandung: Alfabeta.

Wibowo. (2007). Manajemen Kinerja. Jakarta: PT. Raja Grafindo Parsada. 